\title{
Persepsi Orang Tua dalam Penggunaan Gadget Pada Anak SD Di Perkotaan dan Pinggiran Di Kota Blora
}

\author{
Devita Nursovia $^{1)}$, Trixie Salawati ${ }^{1)}$, Rokhani ${ }^{1)}$ \\ ${ }^{1)}$ Fakultas Kesehatan Masyarakat Universitas Muhammadiyah Semarang \\ trixieabu@unimus.ac.id
}

ARTICEL INFO

Accepted :07 Juni 2021

Approve :30 November 2021

Publish :31 Desember 2021

\section{ABSTRACT}

The use of gadgets among children is now starting to increase. According to digital research data, the use of gadgets in Indonesia has increased every year, namely in 2016 as many as 65.2 million, until in 2019 as many as 97 million. Based on observations in Blora, it is known that there are some children who use gadgets without parental supervision and are not given a time limit. So this research was conducted to determine the perceptions of parents in the use of gadgets in elementary school children in urban and suburban areas in Blora City. Comparative research using cross sectional approach. Samples were taken as many as 100 people in urban elementary schools and 100 people in suburban primary schools. Data analysis used normality test using Kolmogorof Smirnov 1 sample test and Independent $t$-test. From the research results, it is known that the majority of respondents in urban areas have a $100 \%$ positive perception. However, only $67 \%$ of respondents in the suburbs had a positive perception. The results of the statistical test on the perceptions of parents in the use of gadgets in urban elementary school children with the parents' perceptions of using gadgets in rural elementary school children, it is known that the value of $p=0.000(p<0.05)$. There is a difference between parents' perceptions of the use of gadgets in urban and suburban elementary school children in the city of Blora with $p$-value $=0.000$.

Keywords : parents' perceptions, gadgets, elementary school children

\begin{abstract}
ABSTRAK
Penggunaan gadget di kalangan anak-anak saat ini mulai mengalami peningkatan. Menurut data riset digital penggunaan gadget di Indonesia mengalami peningkatan setiap tahunnya. Pada tahun 2016 ada sebanyak 65,2 juta pengguna, dan pada tahun 2019 telah menjadi 97 juta pengguna. Berdasarkan observasi fenomena penggunaan gadget pada anak tanpa pengawasan dari orang tua dan tanpa batasan waktu juga terjadi di Kota Blora. Penelitian ini dilakukan untuk mengetahui persepsi orang tua dalam penggunaan gadget pada anak SD di perkotaan dan pinggiran di Kota Blora. Penelitian komparatif dengan menggunakan pendekatan cross sectional. Sampel yang diambil sebanyak 100 orang di SD perkotaan dan 100 orang di SD pinggiran. Analisis data yang digunakan uji Independent t-test. Dari hasil penelitian diketahui bahwa mayoritas responden di
\end{abstract}


perkotaan memiliki persepsi yang positif $100 \%$, namun responden di pinggiran kota yang memiliki persepsi positif hanya $67 \%$. Hasil uji statistik persepsi orang tua dalam penggunaan gadget pada anak SD di perkotaan dengan persepsi orang tua dalam penggunaan gadget pada anak SD di pinggiran, diketahui nilai $\mathrm{p}=0.000$ $(\mathrm{p}<0,05)$. Ada perbedaan antara persepsi orang tua dalam penggunaan gadget pada anak $\mathrm{SD}$ di perkotaan dan pinggiran di kota Blora dengan hasil $(\mathrm{p}=0.000)$.

Kata kunci : persepsi orang tua, gadget, anak SD

\section{PENDAHULUAN}

Gadget sebagai alat komunikasi dapat berfungsi untuk memperluas relasi, menambah wawasan dan pengetahuan (Sutriyatna, 2020). Di Indonesia penggunaan gadget saat ini sudah menjadi hal yang wajar. Menurut data riset digital penggunaan gadget di Indonesia mengalami peningkatan setiap tahunnya yaitu pada tahun 2016 ada sebanyak 65,2 juta pengguna, hingga pada tahun 2019 telah menjadi 97 juta (eMarketer, 2019). Pengguna gadget saat ini bukan hanya dari kalangan dewasa saja namun juga anak-anak. Penelitian di Yogyakarta menunjukkan 94\% anak usia 4-6 tahun sudah menggunakan smarthpone sebagai media edukasi dan bermain (Zaini and Soenarto, 2019). Sedangkan penelitian di Kendal menunjukkan bahwa sebanyak $31 \%$ remaja telah menggunakan gadget $(\mathrm{PH}$, Indrayati and Pratiwi, 2019).

Orang tua memberikan gadget pada anak, karena mereka menganggap bahwa saat ini adalah era digital (Novitasari, 2019). Orang tua memiliki peran penting untuk mengatur anak saat bermain gadget sebagai salah satu pencegahan terhadap paparan negatif dari gadget. Beberapa orang tua sudah memiliki persepsi yang positif terhadap pengaturan penggunaan gadget. Mereka sudah menerapkan tindakan preventif untuk mencegah bahaya yang akan ditimbulkan. Bahkan ada pula orang tua yang memilih melarang anaknya untuk bermain gadget (Amalia and Setyowati, 2019). Anak yang sudah menggunakan gadget perlu mendapat pendampingan orang tua dalam menghadapi perkembangan teknologi saat ini, karena anak-anak masih belum memiliki pengetahuan yang cukup mengenai dampak apa yang terjadi jika terlalu lama bermain gadget (Nanang, 2019) (Donnyanggoro, Bangsa and Malkisedek, 2018). 
Blora merupakan salah satu kota yang ada di Jawa Tengah. Wilayah Kota Blora terbagi menjadi wilayah perkotaan dan pinggiran. Di wilayah perkotaan sebanyak 22,83\% warganya telah berpendidikan tinggi dan sebanyak $10,23 \%$ bekerja di perkantoran (Statistik, 2017) (DINKES, 2018). Masyarakat di pinggiran Kota Blora terdapat 34,70\% yang berpendidikan rendah, dan mereka bekerja sebagai petani karena wilayahnya yang dikelilingi oleh area persawahan (Statistik, 2017) (DINKES, 2018). Seperti halnya yang terjadi di kota-kota lain di Indonesia, saat ini penggunaan gadget pada anak di Kota Blora pun mengalami peningkatan, sebagai bagian dari pelaksanaan pembelajaran di masa Pandemik Covid19. Data pengguna gadget di Kota Blora saat ini belum tersedia, namun berdasarkan observasi ditemukan fenomena umum di mana terdapat anak yang menggunakan gadget tanpa pengawasan dari orang tua dan tidak diberi batasan waktu.

Saat ini orang tua memberikan gadget lebih karena permintaan dari anak untuk menunjang kegiatan pembelajaran selain untuk bermain. Kurangnya informasi serta pemahaman terkait penggunaan gadget dapat menyebabkan orang tua yang ada di Kota Blora tidak mengetahui akan bahaya yang dapat terjadi pada anaknya. Selain itu, tingkat pendidikan seseorang juga dapat mempengaruhi persepsi orang tua dalam memberikan gadget pada anak (Somya and Manjuvani, 2019). Berkaitan dengan hal tersebut, maka penelitian ingin mengetahui bagaimana persepsi orang tua di perkotaan dan di pinggiran Kota Blora mengenai penggunaan gadget pada anak SD.

\section{METODE PENELITIAN}

Jenis penelitian ini adalah penelitian komparatif dengan menggunakan pendekatan cross sectional. Populasi pada penelitian ini yaitu siswa SD kelas 4-6 di Kota Blora yang telah menggunakan gadget. Berdasarkan data Dinas Pendidikan Kabupaten Blora tahun ajaran 2019/2020, dari 30 SD yang ada di area pusat pemerintahan Kota Blora terdapat 3.205 siswa, sedangkan dari 40 SD yang berada di pinggiran Kota Blora terdapat 2.007 siswa. Jumlah tersebut ditentukan menggunakan rumus Slovin. Penentuan sampel dari SD perkotaan dilihat dari SD yang jaraknya $\pm 1 \mathrm{~km}$ dari pusat kota Blora, sedangkan SD pinggiran diambil dari SD yang berada di daerah pedesaan. Selanjutnya besar sampel yang didapat yaitu di SD perkotaan sebanyak 100 orang dan di SD pinggiran sebanyak 100 orang. Analisis data yang digunakan adalah uji Independent t-test. 
HASIL

1. Karakertistik Responden Mayoritas responden di perkotaan berpendidikan tinggi, dan berprofesi sebagai pegawai. Hal ini berbeda dengan responden di pinggiran kota, di mana mayoritas berpendidikan SMP dan bermata pencaharian sebagai petani (Tabel 1)

2. Persepsi Kerentanan Responden Berdasarkan hasil penelitian diketahui bahwa responden di perkotaan memiliki persepsi kerentanan yang positif sebanyak 98\%. Ini menunjukkan bahwa mayoritas responden khawatir jika anak menggunakan gadget sepanjang hari maka anak akan rentan terpapar dampak negatif dari gadget. Sedangkan responden di pinggiran kota yang memiliki persepsi kerentanan yang positif sebanyak $66 \%$. Ini menunjukkan masih ada $34 \%$ responden yang tidak merasa khawatir jika anak menggunakan gadget sepanjang hari maka anak akan rentan terpapar dampak buruk dari gadget. Dari hasil jawaban responden di pinggiran kota diketahui banyak responden yang masih ragu-ragu terhadap kerentanan yang mereka rasakan terkait penggunaan gadget pada anak mereka dibandingkan dengan jawaban responden di perkotaan.

3. Persepsi Keseriusan

Persepsi keseriusan dirasakan oleh 96\% responden di perkotaan. Ini menunjukkan bahwa mayoritas responden merasakan bahwa penyakit yang timbul akibat terlalu sering bermain gadget merupakan penyakit yang berbahaya. Sedangkan responden di pinggiran yang memiliki persepsi keseriusan sebanyak $73 \%$, berarti masih ada $27 \%$ responden yang tidak menganggap serius penyakit yang timbul akibat terlalu sering bermian gadget.

\section{Persepsi Manfaat}

Sebanyak $98 \%$ responden di perkotaan merasakan manfaat dari pengaturan penggunaan gadget pada anak. Sedangkan responden di pinggiran yang merasakan manfaat dari pengaturan gadget pada anak sebanyak 80\%. Ini menunjukkan $20 \%$ responden di pinggiran kota Blora belum merasakan manfaat dari 
pengaturan penggunaan gadget

pada anak.

5. Persepsi Hambatan

Hasil data responden di perkotaan dan di pinggiran kota menunjukkan kesamaan dalam merasakan hambatan untuk berperilaku (22\%). Ini menunjukkan bahwa baik responden di perkotaan maupun di pinggiran kota tidak merasa kesulitan dalam mengatur penggunaan gadget pada anak.

6. Isyarat untuk bertindak

Data responden di perkotaan menunjukkan bahwa $100 \%$ responden memperoleh isyarat untuk mengatur penggunaan gadget pada anak. Sedangkan responden di pinggiran kota, memperoleh isyarat untuk mengatur penggunaan gadget pada anak sebesar $81 \%$. Isyarat tersebut diperoleh baik secara internal maupun eksternal. Isyarat Internal diperoleh melalui tanda-tanda yang diperoleh responden dari perilaku anaknya ketika menggunakan gadget, seperti mata pedih, kesulitan membaca dari jarak jauh hingga insomnia. Sedangkan Isyarat eksternal diperoleh responden dari informasi yang diterimanya dari keluarga dan teman.

7. Perbedaan Persepsi Responden dalam penggunaan gadget pada anak

Secara keseluruhan diperoleh data bahwa $100 \%$ responden di perkotaan memiliki persepsi yang positif tentang pengaturan gadget pada anak. Sedangkan responden di pinggiran kota memiliki persepsi positif tentang pengaturan gadget pada anak hanya $67 \%$.

Hasil uji normalitas menunjukkan bahwa data normal sehingga uji independent sampel $\mathrm{t}$ test. Hasil dari uji statistic menunjukkan rata-rata persepsi orang tua di perkotaan dan di pingiran kota didapatkan nilai $\mathrm{p}=$ 0.000 berarti alpha $(<0.05)$, sehingga ada perbedaan yang signifikan rata-rata persepsi orang tua di perkotaan dan di pingiran kota.

Table 1. Data Distribusi Frekuensi Persepsi Responden 


\begin{tabular}{lcc}
\hline Persepsi Kerentanan terhadap gadget & $98 \%$ & $66 \%$ \\
\hline Persepsi Keseriusan & $96 \%$ & $73 \%$ \\
\hline Persepsi Manfaat & $98 \%$ & $80 \%$ \\
\hline Persepsi Hambatan & $22 \%$ & $22 \%$ \\
\hline Isyarat untuk bertindak & $100 \%$ & $81 \%$ \\
\hline Perbedaan Persepsi tentang pengaturan gadget & $100 \%$ & $67 \%$ \\
\hline
\end{tabular}

Table 2. Data Distribusi Frekuensi Jenis Pekerjaan dan Tingkat Pendidikan Responden

\begin{tabular}{|c|c|c|c|c|c|}
\hline & \multicolumn{2}{|c|}{ Jenis Pekerjaan } & & \multicolumn{2}{|c|}{ Tingkat Pendidikan } \\
\hline & Perkotaan & $\begin{array}{c}\text { Pinggiran } \\
\text { Kota }\end{array}$ & & Perkotaan & $\begin{array}{c}\text { Pinggiran } \\
\text { Kota }\end{array}$ \\
\hline Guru & 22 & - & $\begin{array}{l}\text { Perguruan } \\
\text { Tinggi }\end{array}$ & 52 & - \\
\hline PNS & 15 & - & SMA & 48 & 36 \\
\hline TNI & 6 & - & SMP & - & 42 \\
\hline Marinir & 1 & - & SD & - & 22 \\
\hline Perawat & 10 & - & & & \\
\hline Bidan & 1 & - & & & \\
\hline Satpam & 10 & 1 & & & \\
\hline Wiraswasta & 13 & 8 & & & \\
\hline Swasta & 13 & 23 & & & \\
\hline Petani & - & 46 & & & \\
\hline Buruh & - & 7 & & & \\
\hline IRT & 9 & 15 & & & \\
\hline
\end{tabular}

\section{PEMBAHASAN}

Responden di perkotaan memiliki persepsi yang positif terhadap penggunaan gadget pada anak. Mereka memiliki persepsi kerentanan dan keseriusan yang tinggi terhadap penggunaan gadget pada anak. Hal ini berbeda dengan responden di pinggiran kota, yang memiliki persepsi kerentanan dan keseriusan yang lebih rendah. Perbedaan karakteristik responden dapat menjadi salah satu faktor penentu dari perbedaan persepsi responden, di mana mayoritas responden di perkotaan berpendidikan tinggi, sedangkan responden di pinggiran kota mayoritas berpendidikan SMP. Penelitian di Uttarakhand menunjukkan bahwa ibuibu yang memiliki tingkat Pendidikan yang tinggi lebih peduli terhadap masalah kecanduan gadget pada anak (Somya and Manjuvani, 2019).

Meskipun mayoritas responden di perkotaan khawatir anaknya rentan 
terpapar dampak negatif dari gadget, namun beberapa responden di perkotaan (16\%) menganggap bahwa penggunaan gadget tidak menimbulkan obesitas. Padahal anak yang bermain gadget dalam waktu yang cukup lama cenderung untuk tidak banyak bergerak. Kebiasaan ini dapat meningkatkan risiko terjadinya obesitas (Hasanah, 2017).

Persepsi kerentanan dan keseriusan yang positif dari responden di pinggiran kota lebih rendah dibandingkan dengan responden di perkotaan. Dari jawaban responden di pinggiran kota pada kuesioner terlihat responden di pinggiran kota terlihat belum yakin apakah anak mereka rentan terkena berbagai masalah kesehatan akibat penggunaan gadget. Responden di pinggiran kota juga belum yakin apakah masalah kesehatan yang terjadi sebagai dampak dari penggunaan gadget pada anak adalah masalah yang serius. Hal ini dibuktikan dengan masih banyaknya responden di pinggiran kota yang memilih jawaban ragu-ragu (22\%-32\%) terhadap pertanyaan mengenai persepsi kerentanan dan persepsi keseriusan tentang pengaturan penggunaan gadget pada anak.

Beberapa responden di pinggiran kota merasa ragu apakah penggunaan gadget sepanjang hari dapat mempengaruhi kesehatan reproduksi pada anak, dan dapat mengakibatkan peradangan di jaringan otot tangan. Penggunaan gadget dalam jangka waktu yang lama dengan durasi yang panjang, dapat menimbulkan berbagai risiko, termasuk di dalamnya masalah pada kesehatan reproduksi dan De Quervain Syndrome atau peradangan di jaringan otot bagian tangan (Idayati, 2011) (Samosir, Permata and Muawanah, 2019).

Penggunaan gadget pada anak tanpa adanya batasan waktu dapat mengganggu perkembangan anak. Namun beberapa responden di pinggiran kota menyatakan ragu-ragu jika penggunaan gadget setiap hari dapat mengakibatkan anak terlambat dalam perkembangannya. Anak yang sering menggunakan gadget akan cenderung kurang beraktivitas dengan lingkungan sekitar yang dapat berdampak pada perkembangan yang terhambat, akibatnya anak menjadi terhambat pada kemampuan komunikasi dan prestasi yang menurun (Hasanah, 2017). Pemberian gadget pada anak seharusnya diimbangi dengan pemberian aturan agar anak mengerti batasan atau kapan saatnya mereka boleh bermain gadget. 
Penelitian di Bandar Lampung menunjukkan bahwa penggunaan gadget memiliki dampak negative pada anak jika penggunaannya berlebihan (Simamora, Suntoro and Nurmalisa, 2016).

Hasil analisis data dengan uji $\mathrm{T}$ Test yang dilakukan antara persepsi orang tua dalam penggunaan gadget pada anak SD di perkotaan dengan persepsi orang tua dalam penggunaan gadget pada anak SD di pinggiran, diketahui nilai $\mathrm{p}$ value $=0.000$ yang berarti bahwa ada perbedaan antara persepsi orang tua dalam penggunaan gadget pada anak SD di perkotaan dan pinggiran di kota Blora. Adanya perbedaan persepsi antara masyarakat perkotaan dan pedesaan ini juga terjadi pada penelitian di Semarang tentang perilaku konsumsi susu dan penelitian di Kabupaten Semarang mengenai status gizi antara di pedesaan dan kota (Prastiwi and Setiyawan, 2016)(Fariski, Dieny and Wijayanti, 2020). Hal ini memperjelas bahwa perbedaan karakteristik masyarakat perkotaan dan pinggiran kota menjadi salah satu faktor yang menentukan perbedaan persepsi mereka.

\section{KESIMPULAN}

Ada perbedaan antara persepsi orang tua dalam penggunaan gadget pada anak SD di perkotaan dan pinggiran di kota Blora dengan hasil $p$-value $=0.000$. Perlu adanya edukasi kepada masyarakat khususnya orang tua di pinggiran kota tentang dampak penggunaan gadget pada anak.

\section{REFERENSI}

Sutriyatna, E. (2020) 'Sosialisasi Dampak Penggunaan Gadget Terhadap Anak-Anak ( Studi Kasus Warga Rw . 05 Kelurahan Pondok Petir)', Jurnal Pengabdian Kepada Masyarakat Universitas Pamulang, 1, pp. 133-138.

eMarketer (2019) 'Pengguna Smartphone di Indonesia 2016-2019', databoks, p. 2019.

PH, L., Indrayati, N. and Pratiwi, O. D. (2019) 'Peningkatan Pengetahuan Remaja Melalui Pendidikan Kesehatan Tentang Dampak Penggunaan Gadget', Jurnal Gawat Darurat, 1(2), pp. 77-84.

Novitasari, N. (2019) 'Strategi Pendampingan Orang Tua Terhadap Intensitas Penggunaan Gadget Pada Anak', Al Hikmah: Indonesian Journal Of Early Childhood Islamic Education, 3(2), pp. 167-188.

Amalia, S. and Setyowati, S. (2019) 'Persepsi Orang Tua Terhadap Penggunaan Gadget Pada Anak Usia Dini Di Tk Surabaya', Jurnal PG PAUD.

Nanang, S. (2019) 'Pentingnya Peran Orang Tua Dalam Penggunaan Gadget Pada Anak Usia Dini', JURNAL Smart PAUD, 2(1). 
Donnyanggoro, K. Y., Bangsa, P. G. and Malkisedek, M. H. (2018) 'Perancangan Iklan Layanan Masyarakat Dampak Negatif Penggunaan Gadget Secara Berlebihan Terhadap Tubuh'.

Statistik, B. P. (2017) 'Blora In Figures 2017 '

DINKES (2018) 'PROFIL KESEHATAN Kabupaten Blora Tahun 2017'.

Sowmya, A. S. . and Manjuvani, E. (2019) 'Perceptions of Mothers Towards Children Usage Of Electronic Gadgets', 6, pp. 182-187.

Hasanah, M. (2017) 'Pengaruh Gadget terhadap Kesehatan Mental Anak', Indonesian Jurnal of Islamic Early Childhood Education, 2, pp. 207-214.

Idayati, R. (2011) 'Pengaruh Radiasi Handphone Terhadap Kesehatan', Jurnal Kedokteran Syiah Kuala, 11, pp. 115-120.

Samosir, N. R., Permata, A. and Muawanah, S. (2019) 'Pencegahan Terjadinya Resiko De Quervain Syndrom Pada Pengguna Gadget', Jurnal Pengabdian Masyarakat Multidisiplin, 3(1).

Simamora, A. S., Suntoro, I. and Nurmalisa, Y. (2016) 'Persepsi Orangtua Terhadap Dampak Penggunaan Gadget Pada Anak Usia Pendidikan Dasar'.

Prastiwi, W. D. and Setiyawan, H. (2016) 'Perilaku Konsumsi Susu Cair Masyarakat Di Daerah Perkotaan Dan Pedesaan', 5, pp. 41-53.

Fariski, C., Dieny, F. F. and Wijayanti, H. S. (2020) 'Kualitas Diet, Status Gizi
Dan Status Anemia Wanita Prakonsepsi Antara Desa Dan Kota', Journal of The Indonesian Nutrition Association, 43(1), pp. 11-24. doi: 10.36457/gizindo.v. 